\title{
Association between somatic cell count early in the first lactation and the longevity of Irish dairy cows
}

\author{
S. C. Archer, ${ }^{* 1}$ F. Mc Coy, $†$ W. Wapenaar, ${ }^{*}$ and M. J. Green* \\ *University of Nottingham, School of Veterinary Medicine and Science, Sutton Bonington Campus, Sutton Bonington, Leicestershire, \\ LE12 5RD, United Kingdom \\ †Animal and Grassland Research and Innovation Centre, Teagasc, Moorepark, Fermoy, Co. Cork, Ireland
}

\section{ABSTRACT}

Reduced longevity of cows is an important component of mastitis costs, and increased somatic cell count (SCC) early in the first lactation has been reported to increase culling risk throughout the first lactation. Generally, cows must survive beyond the first lactation to break even on their rearing costs. The aim of this research was to assess the association between SCC of primiparous cows at 5 to 30 days in milk (SCC1), and survival over a 5 -y period for cows in Irish dairy herds. The data set used for model development was based on 147,458 test day records from 7,537 cows in 812 herds. Cows were censored at their last recording if identified at a later date in other herds or if recorded at the last available test date for their herd, otherwise, date of disposal was taken to be at the last test date for each cow. Survival time was calculated as the number of days between the dates of first calving and the last recording, which was split into 50-d intervals. Data were analyzed in discrete time logistic survival models that accounted for clustering of 50-d intervals within cows, and cows within herds. Models were fitted in a Bayesian framework using Markov chain Monte Carlo simulations. Model fit was assessed by comparison of posterior predictions to the observed disposal risk for cows aggregated by parameters in the model. Model usefulness was assessed by cross validation in a separate data set, which contained 144,113 records from 7,353 cows in 808 herds, and posterior predictions were compared with the observed disposal risk for cows aggregated by parameters of biological importance. Disposal odds increased by a factor of $5 \%$ per unit increase in ln SCC1. Despite this, posterior predictive distributions revealed that the probability of reducing replacement costs by $>€ 10$ per heifer calved, through decreasing the herd level prevalence of cows with SCC1 $\geq 400,000$ cells/mL (from an initial prevalence of $\geq 20$ to $<10 \%$ )

Received September 2, 2012.

Accepted January 10, 2013.

${ }^{1}$ Corresponding author: svxsa@nottingham.ac.uk only exceeded $50 \%$ for less than 1 in 5 Irish herds. These results indicate that the effect of a reduction in the prevalence of cows with SCC1 $\geq 400,000$ cells $/ \mathrm{mL}$ on replacement costs alone for most Irish dairy herds is small, and future research should investigate other potential losses, such as the effect of SCC1 on lifetime milk yield.

Key words: dairy heifer, somatic cell count, early lactation, longevity

\section{INTRODUCTION}

Mastitis is well recognized as a costly disease in dairy cows, with losses accrued mainly from decreased milk production and discarded milk (Kossaibati and Esslemont, 1997). However, mastitis has also been associated with reduced longevity (Beaudeau et al., 1993; Seegers et al., 1998), and this has been estimated as the next biggest cost for dairy farmers (Huijps et al., 2008; Heikkilä et al., 2012). Further losses, such as the cost of drugs, veterinary services, diagnostic costs, labor, decreased milk quality, capital investments, and the adverse effects on other diseases (Halasa et al., 2007), are typically less, but may be important for particular herds (Huijps et al., 2008). Premature disposal is of particular relevance for heifers that develop mastitis (Heikkilä et al., 2012), as they must typically reach the second lactation to produce sufficient milk to break even on rearing costs. For example, under Irish conditions, the cost of rearing to the point of calving is approximately €1,451 per heifer (Kennedy et al., 2011). With an average margin over variable costs $€ 0.17 / \mathrm{kg}$ (Hennessy et al., 2011), 8,535 kg of milk is required to break even, which would take $>1$ lactation. Increased longevity of cows reduces demand for replacement heifers and, in turn, provides economic benefits at the farm level, such as the opportunity costs of producing more beef calves, selling surplus heifers, increasing the size of the milking herd, or leasing resources. Alternatively, a surplus of replacement heifers creates the opportunity for increased voluntary culling and selective breeding to improve the genetic merit of the herd. 
Premature culling in the first lactation has been associated with IMI at calving in pasture-based herds in New Zealand (Compton et al., 2007). In Belgian herds, first lactation culling hazard increased by $11 \%$ per unit increase in $\ln$ SCC for primiparous cows at 5 to 14 DIM, and by $32 \%$ when only culling for udder health reasons were considered (De Vliegher et al., 2005). However, the effect of SCC early in the first lactation on lifetime survival has not been evaluated, this is important because the full repercussions of IMI in early life may not become evident until later in life, when maturity is reached and milk yield and financial return are maximized (Madouasse, 2009). As heifers now make up the largest parity group in many Irish herds (ICBF, 2011) following expansion (a trend that may continue in anticipation of the abolition of EU milk quotas in 2015), understanding the repercussions of heifer IMI is of particular importance.

The aim of this research was to assess the association between SCC of parity 1 cows at 5 to 30 DIM (SCC1) and survival over a 5-y period for cows in Irish dairy herds. A Bayesian approach was taken and posterior predictions were used to evaluate the magnitude and financial relevance of this effect, in the context of particular herd scenarios.

\section{MATERIALS AND METHODS}

\section{Data Selection}

To be eligible for inclusion in the study, cows were required to have at least $1 \mathrm{SCC}$ recording between 5 and 30 DIM in parity $1(\mathbf{p} \mathbf{1})$. Cows were selected from a data set of Irish dairy herds based on recordings between 2005 and 2009 (Irish Cattle Breeding Federation, County Cork, Ireland), and 233,176 cows in 7,423 herds were included (p1_data).

Of the selected cows, 893 had more than 1 record between 5 and 30 DIM during parity 1 , and SCC at the first of these was taken as SCC1. Two random samples of 1,000 herds were taken and all records for eligible cows were extracted using $\mathrm{R}$ ( $\mathrm{R}$ Development Core Team, 2010). Not all herds sampled had dates of birth available for cows; for those that did, minimum age at first calving (AFC) was $371 \mathrm{~d}$. Heifers with $\mathrm{AFC}<700$ $\mathrm{d}$ were deemed at increased risk of culling independent of SCC1 because of dystocia (Berry and Cromie, 2009), and individual cows with AFC $<700 \mathrm{~d}$ ( $6 \%$ of the total population) were discarded to remove this effect. Following selection, 147,458 records from 7,537 cows in 812 herds were included in the first sample data set (sample_1), used for model development, and 144,113 records from 7,353 cows in 808 herds in the second (sample_2), used for cross validation.

\section{Definition of Disposal}

Survival time was estimated as the number of days between the dates of first calving and the last recording and was aggregated into 50-d intervals. Disposal (death or culling) was assumed to occur in the last 50-d interval for each cow, in the absence of censoring. In survival analysis, censoring accounts for those cows in the data set for which disposal (the event of interest) may occur when not under observation. This allows them to contribute to the denominator population at risk during the study period (Dohoo et al., 2009). Three reasons were noted for censoring in this study. First, disposal could only occur in the last 50-d interval for each cow, and therefore censoring occurred in every interval survived until the last (this related to the data set structure). Second, cows were censored at the last 50-d interval if identified at a later time in other herds (assumed sold). Third, cows were censored at the last 50-d interval if they were present at the last available test date for the respective herd. Median and interquartile range (IQR) for variables in sample_1, and sample_2 were determined.

\section{Model Development}

Cow disposal was coded as a binary outcome. The discrete time logistic survival model used for analysis took the form

$$
\begin{aligned}
& \operatorname{Disposed}_{\mathrm{ijk}} \sim \text { Bernoulli (probability }=\pi_{i j k} \text { ), } \\
& \operatorname{logit}\left(\pi_{i j k}\right)=\alpha+\operatorname{int}_{i j k}+\operatorname{int}_{i j k}^{2}+\operatorname{int}_{i j k}{ }^{3} \\
& +\mathbf{X}_{i j k} \boldsymbol{\beta}_{1}+\mathbf{X}_{j k} \boldsymbol{\beta}_{2}+\mathbf{X}_{k} \boldsymbol{\beta}_{\mathbf{3}}+\mathrm{v}_{k}+\mathrm{u}_{j k}, \\
& v_{k} \sim \operatorname{Normal}\left(0, \sigma_{v}^{2}\right) \text {, } \\
& u_{j k} \sim \operatorname{Normal}\left(0, \sigma_{u}^{2}\right) \text {, }
\end{aligned}
$$

where the subscripts $i, j$, and $k$ denote the $i$ th $50-\mathrm{d}$ interval, for $j$ th cow, in the $k$ th herd, respectively; $\alpha=$ intercept value; int $=50$-d interval numbered from first calving (included on a ln scale centered on the mean interval number); $\mathbf{X}_{i j k}=$ matrix of exposure variables for each interval; $\boldsymbol{\beta}_{1}=$ vector of coefficients for $\mathbf{X}_{i j k} ; \mathbf{X}_{j k}$ $=$ matrix of exposure variables for each cow; $\boldsymbol{\beta}_{2}=$ vector of coefficients for $\mathbf{X}_{j k} ; \mathbf{X}_{k}=$ matrix of exposure variables for each herd; $\boldsymbol{\beta}_{3}=$ vector of coefficients for $\mathbf{X}_{k} ; v_{k}=$ random effect to account for residual variation between herds (assumed to be a normal distribution with mean $=0$ and variance $=\sigma_{v}^{2}$; $u_{j k}=$ random effect to account for residual variation between cows (as- 
sumed to be a normal distribution with mean 0 and variance $\left.=\sigma_{u}^{2}\right)$. Covariates tested in the model were $\ln$ SCC1 with first test-day milk yield and fat proportion between 5 and 30 DIM in parity 1 (TDY1 and TDF1, respectively), and test-day protein proportion at this time; these continuous variables were centered on their mean value. Days in milk at the first recording was also tested, and this was centered on 5 DIM. Month and year of first calving and month of final recording were investigated as categorical variables.

Time-varying covariates are those that can take different values depending on the 50-d interval, they refer to for a particular cow and are an important consideration in survival analyses (Gröhn et al., 1997). To investigate the effect of time-varying covariates on disposal from the herd, categorical variables were constructed such that missing values in particular 50-d intervals could be included as categories to maintain the structure of the data set, and hence represent time at risk of disposal for each cow. Lagged time-varying covariates from the 2 previous 50-d intervals were investigated for inclusion in the model. The time-varying covariates were: SCC group $(1=<55,000$ cells $/ \mathrm{mL} ; 2=55,000$ to 147,000 cells/mL; $3=\geq 148,000$ cells/mL; and missing), TDY group $(1=<20 \mathrm{~kg} ; 2=20$ to $30 \mathrm{~kg} ; 3=\geq 30 \mathrm{~kg}$; and missing $)$, and DIM group $(1=<100$ DIM; $2=100$ to 199 DIM; $3=200$ to 399 DIM; $4=>399$ DIM; and missing).

To avoid biased parameters associated with likelihood methods (Browne and Draper, 2006), the final model was estimated in WinBUGS 1.4.3 (Lunn et al., 2000), using 10,000 Markov chain Monte Carlo (MCMC) simulations for parameter estimation, following a burn-in of 1,000 MCMC simulations during which time-chain convergence occurred. Initial values for all covariates were generated in MLwiN using penalized quasi-likelihood (Rasbash et al., 2009). Vague prior distributions were used for $\sigma_{v}^{-2} \sim$ Gamma $(0.001,0.001)$, $\sigma_{u}^{-2} \sim$ Gamma $(0.001,0.001)$, and $\boldsymbol{\beta} \sim$ Normal $\left(0,10^{6}\right)$, which meant the data had overriding influence for estimation of parameters (Green et al., 2004). Covariates and interaction terms were selected based on biological plausibility, and when the $95 \%$ Bayesian credible interval (BCI) for the posterior odds ratio distribution excluded 1. Sensitivity of the results to prior distributions for the random effect variances (Spiegelhalter et al., 2004) was evaluated by repeating simulations using the following priors; $\sigma_{v}^{2} \sim$ Uniform $\left(10^{-6}, 10^{6}\right)$, and $\sigma_{u}^{2} \sim$ Uniform $\left(10^{-6}, 10^{6}\right)$.

\section{Model Assessment}

To assess model fit (Green et al., 2009) and usefulness (Gelman et al., 1996), posterior-predicted distributions of disposal risk for subsets sample_1 and sample_2, were generated during the MCMC simulation. The posterior-predictive binomial distribution for the occurrence of disposal in each interval for each cow $\left(\mathrm{y}_{\mathrm{ijk}}\right)$ can be summarized as

$$
y_{i j k} \sim p\left(y_{i j k} \mid \boldsymbol{\beta} \text {, sample_1, } v_{k}, u_{j k}\right) \text {, }
$$

where $p$ represents a conditional probability distribution; $\boldsymbol{\beta}$ is the vector of coefficient distributions; sample_ 1 is the data in the first sample data set; $v_{k}$ and $u_{j k}$ are conditional probability distributions;

$$
\begin{gathered}
v_{k} \sim p\left(v_{k} \mid \sigma_{v}^{2}\right), \\
u_{j k} \sim p\left(u_{j k} \mid \sigma_{u}^{2}\right) ;
\end{gathered}
$$

and $\sigma_{v}^{2}$ and $\sigma_{u}^{2}$ are posterior predictive distributions for herd, and cow level random effect variances, respectively. To assess model fit, the subsets of sample_1 used for posterior predictions were data relating to parameters from the final model: 50-d interval from first calving, calendar month of first calving, and calendar month of last recording. To assess model usefulness, the subsets of sample_1 used for posterior predictions were data that were not used for parameter estimation in the final model, these were: SCC1 group $(1=<50,000 / \mathrm{mL}$; $2=50,000$ to $99,000 / \mathrm{mL} ; 3=100,000$ to $164,000 / \mathrm{mL}$; $4=\geq 164,000 / \mathrm{mL}$ ), estimated bulk milk SCC (BMSCC) group (geometric mean BMSCC estimated from all cow test day SCC records available for each herd, weighted by all TDY records in the full data set; $1=$ $<200,000 / \mathrm{mL} ; 2=200,000$ to $249,000 / \mathrm{mL} ; 3=250,000$ to $399,000 / \mathrm{mL} ; 4=>399,000 / \mathrm{mL})$, and AFC group (1 $=<730 \mathrm{~d} ; 2=730$ to $759 \mathrm{~d} ; 3=760$ to $849 \mathrm{~d} ; 4=>849$ d). To investigate whether results could potentially be generalized to other Irish herds, prediction of the conditional binomial distribution for the occurrence of disposal $\left(y_{i j k}^{\mathrm{xval}}\right)$, for cows in subsets based on SCC1 and BMSCC in sample_2, were made thus:

$$
y_{i j k}^{\mathrm{xval}} \sim p\left(y_{i j k}^{\mathrm{xval}} \mid \boldsymbol{\beta}, \text { sample_2 }\right),
$$

where $\boldsymbol{\beta}$ is the vector of coefficient distributions and sample_2 is the data in the second sample data set, which was not used for estimating parameters in the final model.

\section{Micro-Simulation of Herd Scenarios}

To illustrate the effect of SCC1 on survival at herd level and to demonstrate financial relevance, a procedure 
Table 1. Frequency of 7,423 Irish herds categorized by prevalence of cows with $\mathrm{SCC} 1^{1} \geq 400,000$ cells $/ \mathrm{mL}$, and mean and (variance) for normally distributed variables measured at 5 to 30 DIM in 233,176 parity 1 cows in these herds; values were used to simulate the economic effect of herd-level reductions in the prevalence of cows with SCC1 $\geq 400,000$ cells $/ \mathrm{mL}$

\begin{tabular}{lcccc}
\hline & \multicolumn{4}{c}{ SCC1 $\geq 400,000$ cells $/ \mathrm{mL}$} \\
\cline { 2 - 5 } Item & $\geq 10 \%$ & $\geq 20 \%$ & $<5 \%$ & $<10 \%$ \\
\hline Percentage of herds & 55 & 19 & 25 & 45 \\
SCC1 $^{2}($ cells $/ \mathrm{mL})$ & 120,000 & 170,000 & 71,000 & 81,000 \\
ln SCC1 $_{\text {TDY1 }}^{3}$ & $4.79(1.52)$ & $5.11(1.78)$ & $4.26(0.80)$ & $4.39(1.04)$ \\
TDF1 $^{5}$ & $22.4(30.0)$ & $21.6(32.3)$ & $-{ }_{4}$ & - \\
\hline
\end{tabular}

${ }^{1}$ First test-day SCC record between 5 and 30 DIM in parity 1 .

${ }^{2}$ Geometric mean.

${ }^{3}$ First test-day milk yield record (kg) between 5 and 30 DIM in parity 1 .

${ }^{4}$ Indicates levels used in the simulation were unchanged.

${ }^{5}$ First test-day fat record (proportion) between 5 and 30 DIM in parity 1 .

known as micro-simulation was used (Spiegelhalter et al., 2004). This method involves a simulation to model the trajectory of individual cows, and thus evaluate the expected outcomes for particular scenarios with all variability in the model parameters and dependence between variables being included (Spiegelhalter et al., 2004). Therefore, the Bayesian model was extended to include a one-step micro-simulation of disposal risk for 1,000 theoretical cows with different characteristics in herds with $\geq 10$ or $\geq 20 \%$ initial prevalence of cows with SCC1 $\geq 400,000$ cells $/ \mathrm{mL}$. The SCC1 threshold of $\geq 400,000$ cells $/ \mathrm{mL}$ was used to give relatively high specificity for identifying heifers with putative IMI (Bradley and Green, 2005). Initial herd-level prevalence group cutoffs were selected based on the observed distributions of cows with SCC1 $\geq 400,000$ cells/mL in p1_data (Table 1), and data from the first milk recording at 5 to 30 DIM for heifers in these groups were simulated from normal distributions determined from p1_data (Table 1). Scenarios were used such that for herds with $\geq 10 \%$ of cows with $\mathrm{SCC} 1 \geq 400,000$ cells $/ \mathrm{mL}$ this was reduced this to $<5 \%$, and for herds with $\geq 20 \%$ of cows with SCC1 $\geq 400,000$ cells $/ \mathrm{mL}$ this was reduced to $<5$ or $<10 \%$. To model these changes, distributions for $\mathrm{ln}$ SCC1 were used as shown in Table 1. Distributions for TDY1, and TDF1 remained unchanged to demonstrate solely the effect on disposal risk of achievable reductions in the herd-level prevalence of cows with SCC1 $\geq 400,000$ cells $/ \mathrm{mL}$. For a straight-forward comparison between different herd scenarios, all simulated heifers had a first calving in February aged 24 mo and a final recording in December. The conditional predicted binomial distribution for the occurrence of disposal $\left(\operatorname{pred}_{\mathrm{ij}}\right)$ in each 50-d interval (i) for each cow (j) was

$$
\operatorname{pred}_{i j} \sim p\left(\operatorname{pred}_{i j} \mid \boldsymbol{\beta}, \mathbf{X}^{\text {sim }}\right),
$$

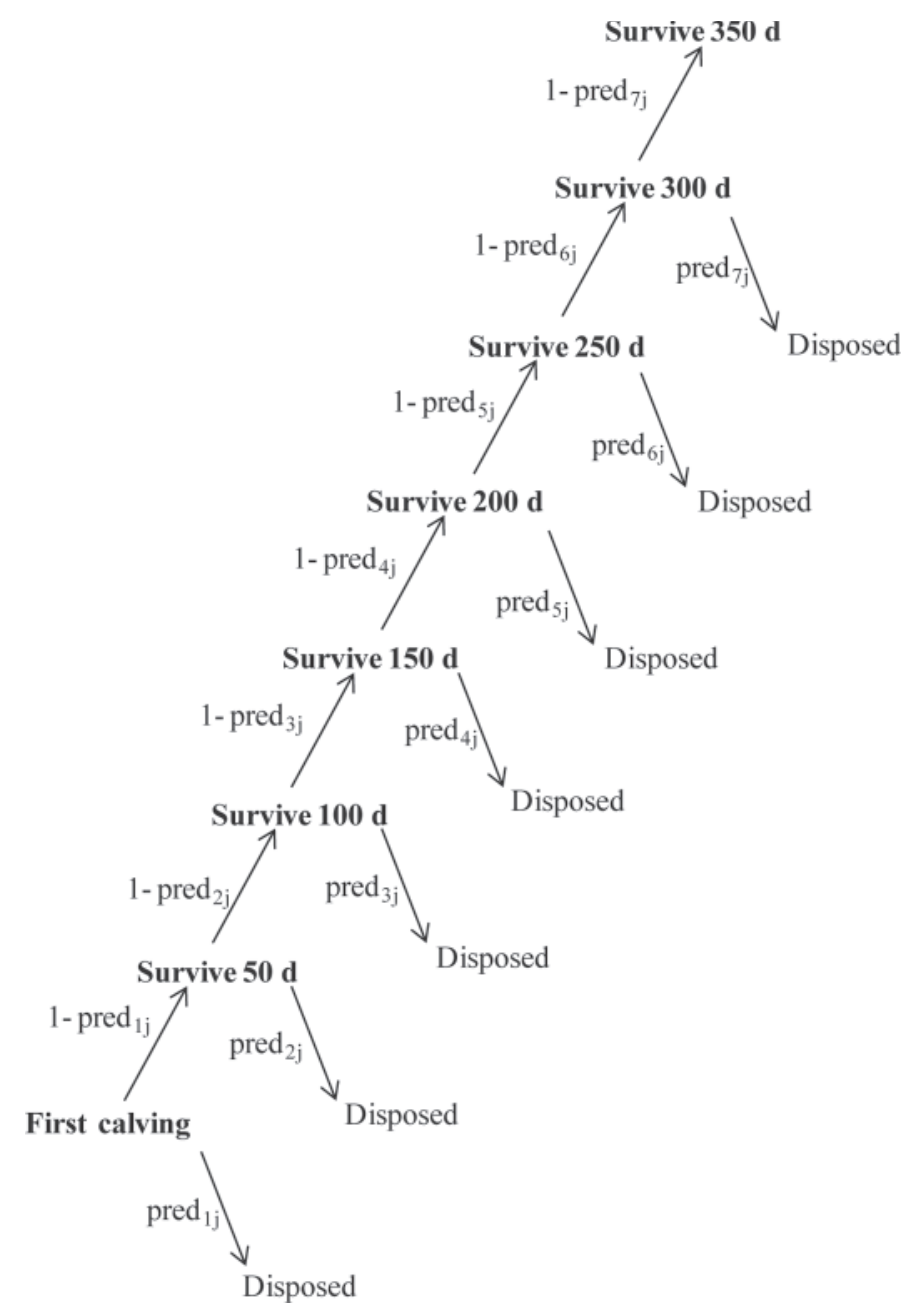

Figure 1. Diagram to represent calculation of the probability of cow disposal (probability of disposal in the $i$ th interval for the $j$ th cow $=\operatorname{pred}_{i j}$ ) within $350 \mathrm{~d}$ from first calving [probability of disposal within $350 \mathrm{~d}$ from first calving $=1-($ probability of surviving $350 \mathrm{~d})]$. 
Table 2. Descriptive statistics for cows with a recording 5 to 30 DIM from first calving in random samples of 812 and 808 Irish dairy herds ${ }^{1}$

\begin{tabular}{lll}
\hline Item & 812 -herd model & 808-herd cross-validation model \\
\hline Cows (no.) & 7,537 & 7,353 \\
Cows disposed (no.) & 4,101 & 3,944 \\
Median mo of first calving (IQR $\left.{ }^{3}\right)$ & April 2005 (Feb. 2005-Feb. 2006) & April 2005 (Feb. 2005-Feb. 2006) \\
Median age at first calving (IQR) & $2.1(2.0-2.3)$ y & $2.1(2.0-2.4) \mathrm{y}$ \\
Median SCC $^{4}$ (IQR) & $86,000(51,000-172,000)$ cells $/ \mathrm{mL}$ & $85,000(49,000-176,000) \mathrm{cells} / \mathrm{mL}$ \\
Median test day milk yield (IQR) & $23(19-26) \mathrm{kg}$ & $23(19-26) \mathrm{kg}$ \\
Median test day fat proportion $^{4}$ (IQR) & $0.040(0.036-0.045)$ & $0.040(0.036-0.045)$ \\
Median test day protein proportion $^{4}$ (IQR) & $0.032(0.030-0.034)$ & $0.032(0.030-0.034)$ \\
Median time at risk $^{5}$ (IQR) & $3.7(2.8-4.5) \mathrm{y}$ & $3.7(2.8-4.5) \mathrm{y}$ \\
\hline
\end{tabular}

${ }^{1}$ Based on herd test day data from 2005 to 2009.

${ }^{2}$ Discrete time logistic survival model for cow disposal in any 50-d interval from first calving.

${ }^{3}$ Interquartile range.

${ }^{4}$ At the first recording between 5 and 30 DIM following the first calving.

${ }^{5}$ Time between date of first calving and date of last recording.

where $\boldsymbol{\beta}$ is the vector of coefficient distributions in the final model and $\mathbf{X}^{\text {sim }}$ is a matrix of simulated exposure variables for the cows; which included ln SCC1, TDY1, and TDF1 that were drawn from the distributions in Table 1, 50-d interval, month of last recording, and DIM category. Risk of disposal from the herd within the $350,700,1,050,1,400$, and $1,750 \mathrm{~d}$ after first calving was calculated from the conditional probability of each cow surviving subsequent $50 \mathrm{~d}$ intervals, thus

disposal risk within n $50-d$ intervals $j=1-\left(\prod_{i=1}^{n} 1-\operatorname{pred}_{i j}\right)$,

where $\operatorname{pred}_{i j}$ is the probability of disposal in the $i$ th interval for the $j$ th cow. An example of this calculation is given in Figure 1 for disposal risk within $350 \mathrm{~d}$ from first calving $(\mathrm{n}=7)$. The calculated disposal risk for each cow $(\mathrm{j})$ was then used to draw from a Bernoulli distribution if each cow would be disposed (as a binary outcome) within $\mathrm{n} 50$-d intervals (i) from first calving, thus: disposed within $\mathrm{n}$ 50-d intervals ${ }_{j} \sim$ Bernoulli $\left[\operatorname{probability}=1-\left(\prod_{i=1}^{n} 1-\operatorname{pred}_{i j}\right)\right]$.

The difference in the number of cows disposed over time in the simulated herds following reductions in the prevalence of cows with $\mathrm{SCC} 1 \geq 400,000$ cells $/ \mathrm{mL}$ was multiplied by a replacement cost of $€ 1,451$ per cow (Kennedy et al., 2011) to give an estimated reduction in herd disposal cost attributable to changes in herd level prevalence of cows with SCC1 $\geq 400,000$ cells/mL; this was expressed as the cost $(€)$ per heifer calved into the herd. Following 10,000 MCMC simulations, the posterior probabilities of magnitudes of saving within $1,750 \mathrm{~d}$ of first calving were plotted as a cumulative frequency distribution to illustrate the likelihood of different cost benefits. The posterior probability (Bayesian $P$-value; Gelman et al., 1995) that disposal risk was higher for cows in herds with $\geq 20 \%$ initial prevalence of cows with SCC1 $\geq 400,000$ cells/mL, compared with the same herds following reduction in prevalence to $<5 \%$ was determined.

\section{Micro-Simulation of Baseline Disposal Risk}

To aid interpretation, the effect of SCC1 on disposal risk was investigated on a continuous scale with $\ln$ $\mathrm{SCC}^{\mathrm{SIM}}$ defined as uniform $(0,9.2)$, to include the full range of possible values. Predictions were based on draws from this distribution for baseline cows (base; February calving, AFC $=24$ mo, last recording in December, $<100$ DIM, TDY $1=23 \mathrm{~kg} / \mathrm{d}$, TDF $1=0.04$, at 450 to $500 \mathrm{~d}$ from first calving), thus

$$
\text { base } \sim p\left(\text { base } \mid \boldsymbol{\beta}, \mathbf{X}^{\mathrm{SIM} 2}\right),
$$

where $p$ represents a conditional probability distribution; $\boldsymbol{\beta}$ is the vector of coefficient distributions; and $\mathbf{X}^{\mathrm{SIM} 2}$ is a matrix of data for the simulated cows. Simulations were repeated for groups of cows that were 100 to 199, and 200 to 304 DIM. Regression lines were estimated for the posterior relationship between $\ln$ $\mathrm{SCC} 1^{\mathrm{SIM}}$, and risk of disposal in each group.

\section{RESULTS}

\section{Descriptive Results}

Descriptive statistics for sample_1 and sample_2 were similar (Table 2). In sample_1, median SCC1 was 86,000 cells/mL (IQR 51,000-172,000 cells/mL), and $54 \%$ of cows were disposed of during the study period after a median time at risk of $3.7 \mathrm{yr}$ (IQR 2.8-4.5 yr). Distributions of SCC1, time at risk, and AFC were right skewed. Distributions of other variables from the first recording (TDY1, TDF1, and TDP1) were normal. Four percent of cows moved to other herds and were censored. 
Table 3. Final models ${ }^{1}$; $95 \%$ Bayesian credible intervals for the odds ratios for cow disposal from 812 Irish dairy herds, based on 10,000 simulations

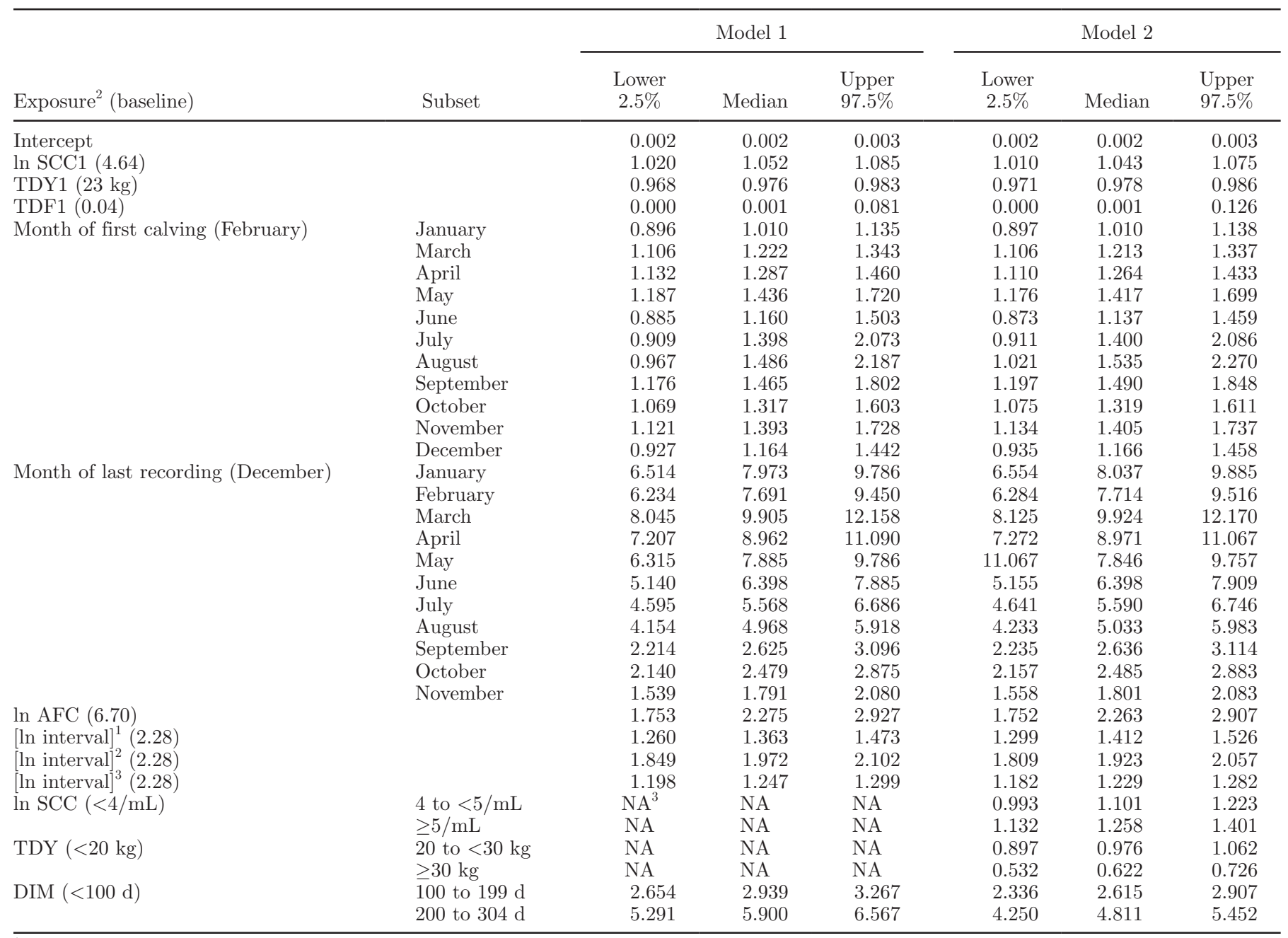

${ }^{1}$ Discrete time logistic survival models for cow disposal in any 50-d interval from first calving. Model 1 includes SCC1 only. Model 2 includes further time-varying covariates.

${ }^{2}$ ln SCC1 = first test-day SCC record between 5 and 30 DIM in parity 1; TDY1 = first test-day milk yield record (kg) between 5 and 30 DIM in parity 1 ; TDF $1=$ first test-day fat record (proportion) between 5 and 30 DIM in parity 1 ; AFC $=$ age at first calving (d); interval $=50$ - $\mathrm{d}$ intervals from first calving (included as polynomials); ln SCC $=$ SCC category in the penultimate interval for each cow (missing category not shown); TDY = test-day milk yield category in the penultimate interval for each cow (missing category not shown); and DIM = DIM category in the penultimate interval for each cow (missing category not shown).

${ }^{3} \mathrm{NA}=$ not applicable.

\section{Model Results}

The final models are presented in Table 3. For Model 1, which focused on SCC1 as the exposure of interest, the median odds of a cow disposal in any 50-d interval increased by $5 \%$ [median odds ratio $(\mathbf{M O R})=1.05$; $95 \%$ BCI $=1.02-1.09]$, with every unit increase in SCC1 (as a ln linear score). Increased milk and fat proportions (TDY1 and TDF1), were negatively associated with disposal; unit and 0.01 unit increases were associated with $2 \%(\mathrm{MOR}=0.98 ; 95 \% \mathrm{BCI}=0.97-0.98)$, and $7 \%$ $(\mathrm{MOR}=0.93 ; 95 \% \mathrm{BCI}=0.89-0.98)$ reductions in the odds of disposal in each interval respectively. Decrease in AFC from 27 to 24 mo was associated with a $10 \%$ reduction in the odds of disposal (MOR $=0.90 ; 95 \%$ $\mathrm{BCI}=0.93-0.88)$. Cows with a first calving in November had the highest odds of disposal, 39\% (MOR = $1.39 ; 95 \%$ BCI $=1.12-1.73$ ) greater than those calving in February; cows with their last recording in March had the highest odds of disposal, 10 times higher (MOR $=9.90 ; 95 \%$ BCI $=8.04-12.16$ ) than cows with their last recording in December. Random effect variance was greater at herd level than cow level (Table 4), indicating more variation in cow disposal between herds than between cows within herds. A $<3 \%$ difference was noted in the MOR, and limits of the $95 \%$ BCI when 
Table 4. Random effect variances from final models $^{1} ; 95 \%$ Bayesian credible intervals for $\ln$ odds of cow disposal from 812 Irish dairy herds, based on 10,000 simulations

\begin{tabular}{|c|c|c|c|c|c|c|}
\hline \multirow[b]{2}{*}{ Level } & \multicolumn{3}{|c|}{ Model 1} & \multicolumn{3}{|c|}{ Model 2} \\
\hline & $\begin{array}{c}\text { Lower } \\
2.5 \%\end{array}$ & Median & $\begin{array}{l}\text { Upper } \\
97.5 \%\end{array}$ & $\begin{array}{c}\text { Lower } \\
2.5 \%\end{array}$ & Median & $\begin{array}{l}\text { Upper } \\
97.5 \%\end{array}$ \\
\hline Cow & 0.0003 & 0.0009 & 0.009 & 0.0005 & 0.001 & 0.003 \\
\hline Herd & 0.225 & 0.284 & 0.352 & 0.233 & 0.291 & 0.356 \\
\hline
\end{tabular}

${ }^{1}$ Discrete time logistic survival model for cow disposal in any 50-d interval from first calving. Model 1 includes SCC1 only. Model 2 includes further time-varying covariates.

uniform prior distributions were used for the random effect variances; this had no substantive effect on model interpretation.

\section{Inclusion of Time-Varying Covariates}

Cows in late lactation had higher median odds of disposal in the subsequent 50-d interval (Table 3); MOR were $2.9(95 \% \mathrm{BCI}=2.65-3.27)$ and $5.9(95 \% \mathrm{BCI}$ $=5.29-6.57)$ for those cows 100 to 199 DIM and over 199 DIM, respectively, compared with those $<100$ DIM (Model 1; Table 3). With the other time-varying covari- ates added (Model 2; Table 3) results were similar, and cows in late lactation also had higher odds of disposal in the subsequent 50-d interval; median odds ratios were $2.6(95 \% \mathrm{BCI}=2.34-2.91)$ and $4.8(95 \% \mathrm{BCI}=$ 4.25-5.45) for those cows 100 to 199 DIM and over 199 DIM, respectively, compared with those $<100$ DIM. In Model 2, the time-varying SCC categories 55,000 to 147,000 cells $/ \mathrm{mL}$ and $\geq 148,000$ cells $/ \mathrm{mL}$ were associated with $10 \%(\mathrm{MOR}=1.10 ; 95 \% \mathrm{BCI}=1.00-1.22)$ and $26 \%(\mathrm{MOR}=1.26 ; 95 \% \mathrm{BCI}=1.13-1.40)$ increased odds of disposal in the subsequent 50-d interval, respec-
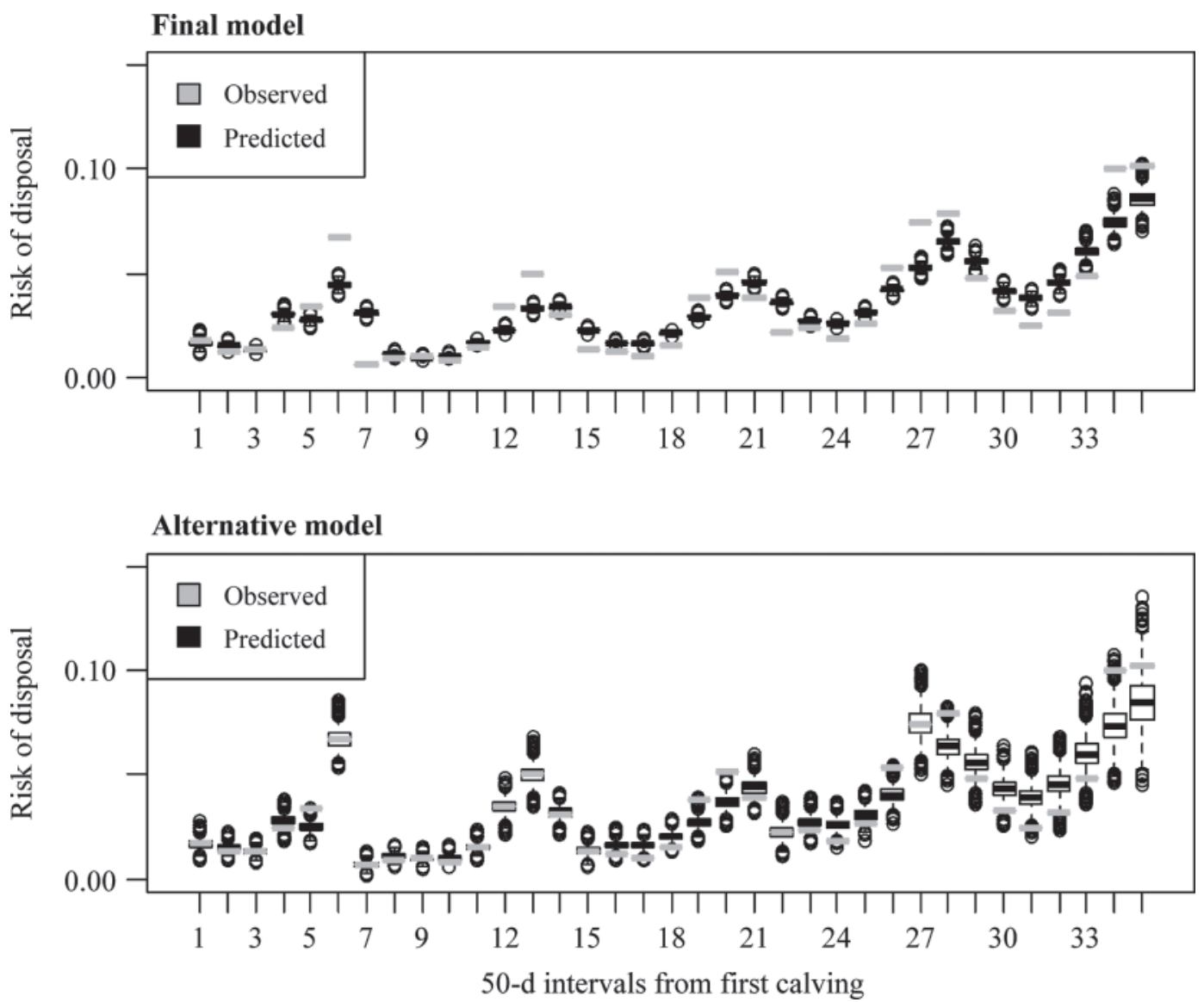

Figure 2. Predictions from 10,000 simulations of the final and alternative versions (alternative model includes 7 additional categorical terms to improve fit to observed data) of Model 1 (discrete time logistic survival model for cow disposal in any 50-d interval from first calving) to assess internal fit; disposal risk in each 50-d interval from first calving, and observed values in 812 Irish dairy herds used for model development. 
Within-model predictions

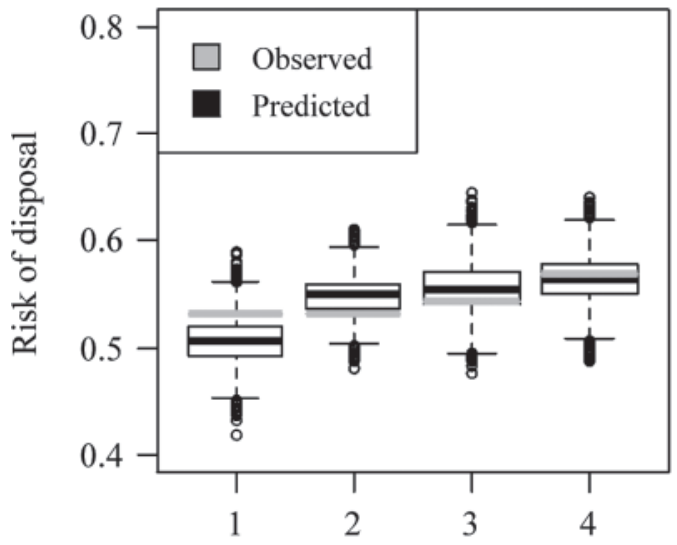

Fixed effect cross validation

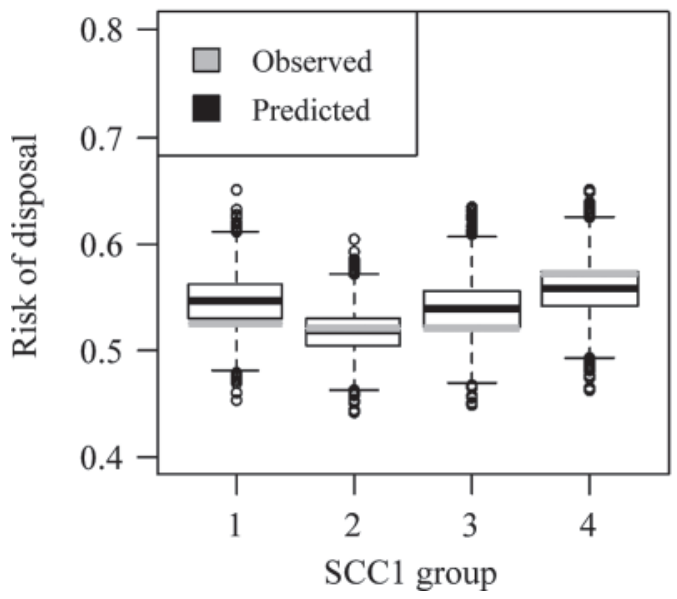

Within-model predictions

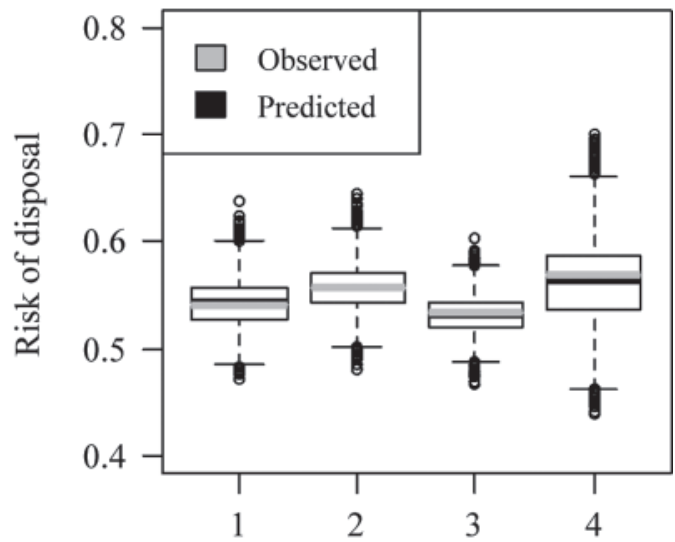

Fixed effect cross validation

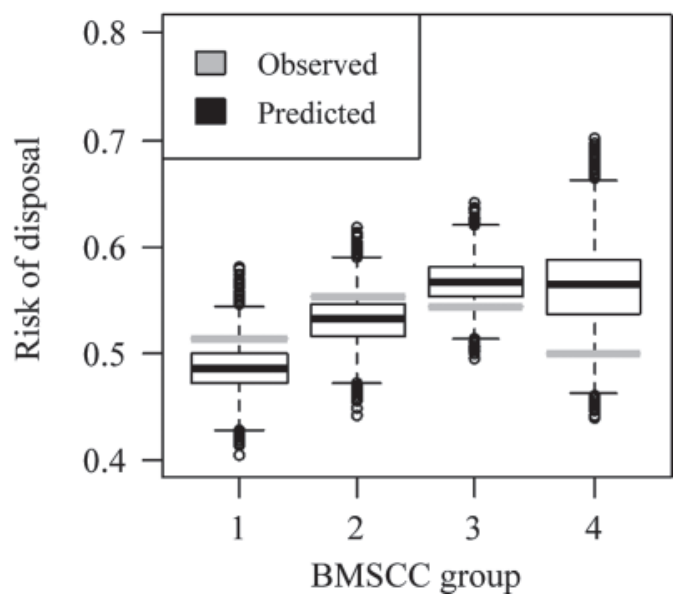

Figure 3. Fixed-effect predictions of disposal risk from 10,000 simulations of Model 1 (discrete time logistic survival model for cow disposal in any 50-d interval from first calving) and observed values in 812 Irish dairy herds used for model development to assess within-model fit, and in 808 separate Irish dairy herds used for cross validation (indicates results can be generalized to other Irish dairy herds), grouped by SCC (group $1=<50,000$ cells $/ \mathrm{mL}$; group $2=50,000$ to 99,000 cells $/ \mathrm{mL}$; group $3=100,000$ to 164,000 cells $/ \mathrm{mL}$; group $4=\geq 164,000$ cells $/ \mathrm{mL}$ ) at 5 to 30 DIM in parity 1 (SCC1), and estimated herd bulk milk SCC (BMSCC) group (geometric mean BMSCC estimated from cow test day SCC, and milk records: group $1=<200,000$ cells/mL; group $2=200,000$ to 249,000 cells/mL; group $3=250,000$ to 399,000 cells/mL; group $4=>399,000$ cells $/ \mathrm{mL}$ ).

tively, compared with cows with SCC $<55,000$ cells/ $\mathrm{mL}$. With these time-varying SCC categories added, the strength of association (MOR) between ln SCC1 and disposal decreased by $0.9 \%$ compared with Model 1 , indicating that part of this effect is mediated through an association with SCC at later recordings (Table 3). Time-varying covariates for TDY were associated with $2 \%(\mathrm{MOR}=0.98 ; 95 \% \mathrm{BCI}=0.90-1.82)$ and $38 \%$ $(\mathrm{MOR}=0.62 ; 95 \% \mathrm{BCI}=0.53-0.73)$ decreased odds of disposal in the subsequent 50-d interval for cows with TDY of 20 to $<30 \mathrm{~kg}$ and $\geq 30 \mathrm{~kg}$, respectively, compared with cows with TDY $<20 \mathrm{~kg}$. Association of TDY1 with disposal from the herd was unchanged. Two models are presented because the effect of timevarying covariates in Model 2 is useful to identify pos- sible reasons for disposal of particular cows (Table 3 ). However, the main aim of the research was to evaluate the effect of SCC1 on cow disposal risk, specifically to focus on information available by 30 DIM in parity 1 . It was therefore decided that further predictions and simulations would be based on Model 1.

\section{Model Assessment}

To demonstrate the internal fit of Model 1 (Table 3) to sample_1, posterior-predicted risk of disposal by interval is shown in Figure 2. The observed data had a cyclical pattern, with higher risk of disposal in particular intervals. Although the 50-d time intervals relate to cow-time from the date of first calving, the 
majority of cows in the data set calved in spring (February to April), and thus cyclicity occurred because of an increased risk of disposal each autumn, when cows were in late lactation. A time-varying term for DIM was required to improve model fit to the observed data, although small discrepancies remained for certain intervals. Categorical terms for 7 intervals were added to the model, which improved the fit, shown as the alternative model (Figure 2); however, odds ratio distributions were not deemed to change by a meaningful extent ( $<1 \%$ difference in MOR and limits of the $95 \%$ BCI), and the parsimonious model was retained. Predictions of disposal risk by month of first calving, and month of last recording in sample_1 indicated good model fit (not shown).

In terms of the usefulness of Model 1, close agreement was noted between predicted and observed disposal risk for cows grouped by SCC1, BMSCC (Figure 3), and AFC (not shown). Within model fit was good, as observed values were within the $95 \%$ BCI of predictions. This was also the case on cross validation, and these results indicate that, in terms of SCC1, BMSCC, and AFC, Model 1 appeared to be generalizable to other Irish herds.

\section{Micro-Simulation of Baseline Disposal Risks}

Results based on Model 1 are presented graphically; the relationship between risk of disposal from the herd and SCC1 is shown for cows in different stages of lactation (Figure 4). Regression lines (on an ln scale), had slopes of $0.0011,0.00061$, and 0.0031 , and intercepts of $0.0022,0.013$, and 0.0064 for cows that were $<100,100$ to 199 , and 200 to 304 DIM, respectively.

\section{Micro-Simulation of Herd Scenarios}

The posterior probability of disposal was greater for cows in herds with $\geq 20 \%$ initial prevalence of cows with SCC1 $\geq 400,000$ cells/mL compared with the same herds after a reduction in prevalence to $<5 \%$, for 65 , $68,74,75$, and $73 \%$ of simulations within 350,700 , $1,050,1,400$, and $1,750 \mathrm{~d}$ from first calving, respectively (Figure 5). Figure 6 shows the estimated probability of different levels of potential savings per heifer calved into the herd attributable to reduced replacement costs within $1,750 \mathrm{~d}$ for various herd-level reductions in the prevalence of cows with SCC1 $\geq 400,000$ cells/ $\mathrm{mL}$. Herds with $\geq 20 \%$ prevalence of heifers with SCC1 $\geq 400,000$ cells $/ \mathrm{mL}$ had $54 \%$ probability of a cost savings of $\geq € 10$ per heifer in the herd through reducing the prevalence of heifers with SCC1 $\geq 400,000$ cells $/ \mathrm{mL}$ to $<10 \%$ (Figure 6 ). For example, for a herd that calves 20 heifers per year, this equates to a saving of $€ 200 / \mathrm{yr}$

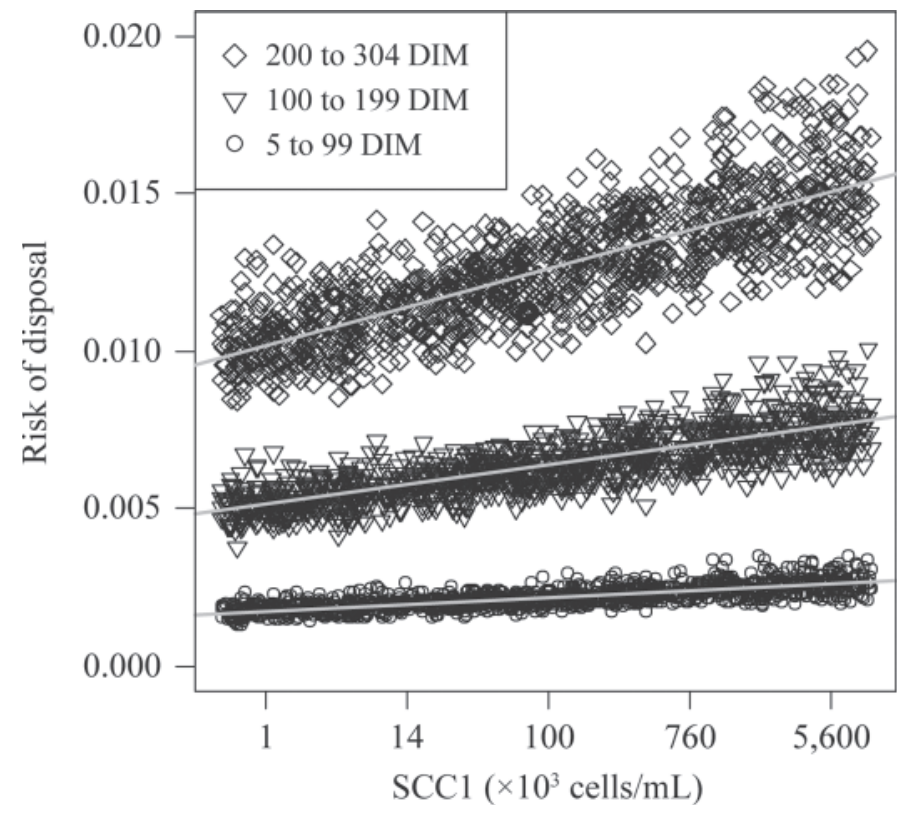

Figure 4. Scatter plot and regression lines from 1,000 simulations of Model 1 (discrete time logistic survival model for cow disposal in any 50-d interval from first calving); posterior predicted risk of disposal between 450 and $500 \mathrm{~d}$ from first calving, against SCC at 5 to 30 DIM (SCC1). Refers to cows calving in February, aged 24 mo, that produced $23 \mathrm{~kg} / \mathrm{d}$ of milk with $4 \%$ fat between 5 and 30 DIM, and had their last recording in December, but at different stages of lactation.

through decreased replacement rate; further scenarios for the example herd are given in Table 5. When only the first $350 \mathrm{~d}$ from first calving (first lactation) are included in the economic simulation, the results are ostensibly the same, indicating that at herd-level the effect of SCC1 on disposal risk is greater over a shorter time period, or, conversely, other reasons for disposal become more important as the time period considered increases.

\section{DISCUSSION}

Somatic cell count in the first month of lactation during parity 1 was positively associated with risk of disposal from the herd, although the size of this effect appeared relatively small. A possible reason for this is that, in practice, other considerations have an overriding influence on cow disposal decisions. The effect of time-varying covariates in explaining cow disposal risk was demonstrated (Model 2), and this emphasizes the importance of recent health and production records in making disposal decisions. In seasonally calving herds, those cows not pregnant at the end of the breeding season may be at higher disposal risk at the end of lactation (Pinedo et al., 2010), in some herds this may limit the number of cows that can be removed for other reasons. Herd circumstances, such as the availability 
$350 \mathrm{~d}$

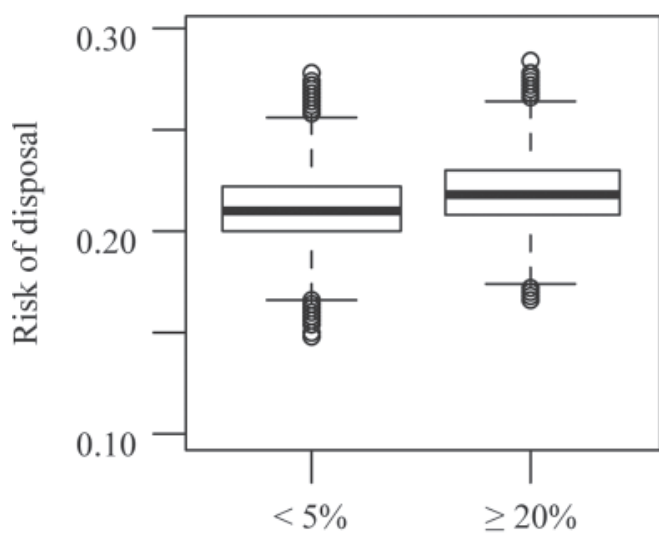

$\mathrm{SCC} 1 \geq 400,000$ cells $/ \mathrm{mL}$

$1,050 \mathrm{~d}$

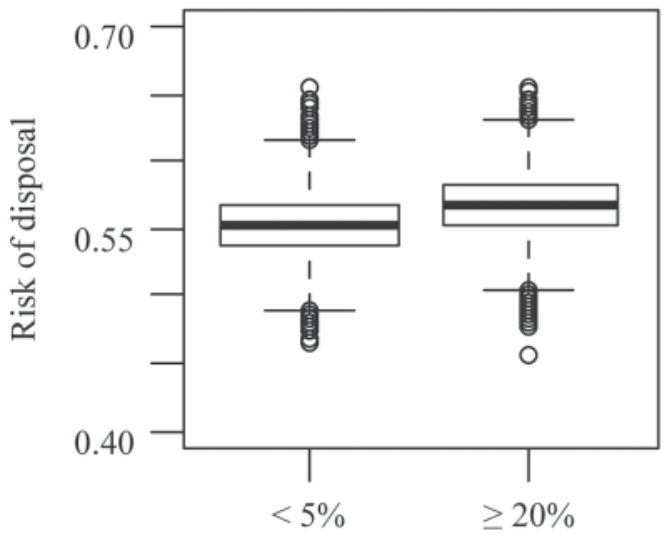

$\mathrm{SCC} 1 \geq 400,000$ cells $/ \mathrm{mL}$
$700 \mathrm{~d}$

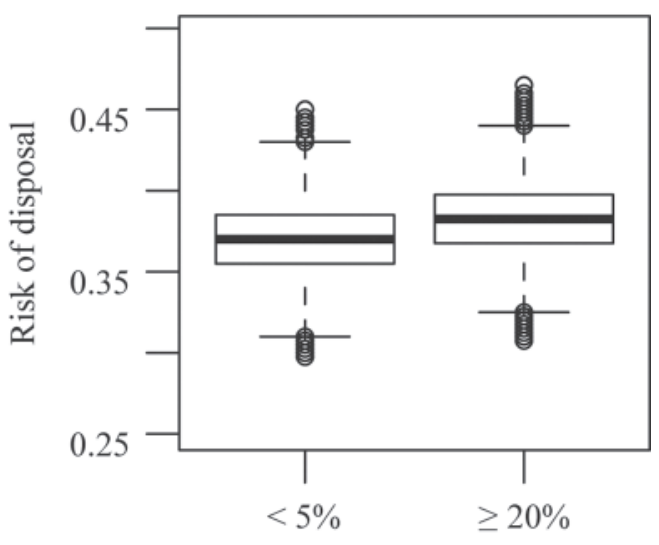

$\mathrm{SCC} 1 \geq 400,000$ cells $/ \mathrm{mL}$

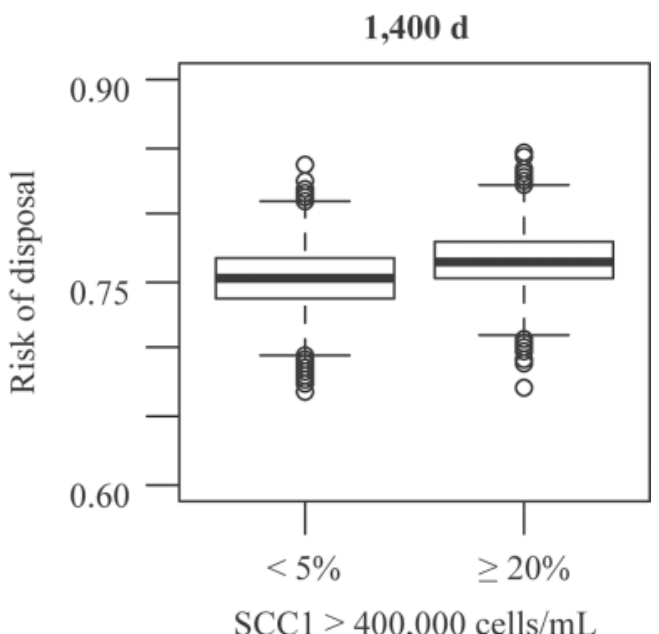

Figure 5. Micro-simulation over 10,000 simulations of Model 1 (discrete time logistic survival model for cow disposal in any 50-d interval from first calving); cow disposal risk within 350,700, 1,050, and 1,400 d from first calving in herds with $\geq 20 \%$ initial prevalence of cows with SCC at 5 to 30 DIM in parity 1 (SCC1) $\geq 400,000$ cells $/ \mathrm{mL}$, and following a reduction in prevalence to $<5 \%$.

of replacement heifer and space in the dairy unit, may also influence disposal decisions (Lehenbauer and Oltjen, 1998); for European Union herds, milk quota availability may also require consideration. In the current study, more variation in cow disposal risk was identified between herds than within herds, indicating that decisions on cow disposal do appear to be herd specific (Weigel et al., 2003) and may therefore reflect the underlying management objectives.

When the cost of potential interventions are considered, as a result of the small effect size and uncertainty in the outcome, reductions in the prevalence of cows between 5 and 30 DIM during parity 1 with SCC $\geq 400,000$ cells $/ \mathrm{mL}$ appear only marginally beneficial in terms of reduced disposal costs for less than 1 in 5 Irish dairy herds with a prevalence $\geq 20 \%$ (Table 1 ). This judgment, however, depends on the decision makers' attitude to risk (Figure 6) and how much uncertainty in a particular outcome they are comfortable with. If control measures to reduce SCC between 5 and 30 DIM during parity 1 were to be considered, they should focus on the prepartum period (Green et al., 2007, 2008). Further research is needed to include the effect of SCC

Table 5. Model $1^{1}$ predictions for an example herd that calves 20 heifers/yr; probability of annual savings through decreased replacement costs within 1,750 d of first calving associated with reductions in the number of heifers with SCC $\geq 400,000$ cells $/ \mathrm{mL}$ between 5 and 30 DIM

\begin{tabular}{lccc}
\hline & \multicolumn{3}{c}{ Change in number of parity 1 cows $(/ 20)$} \\
\cline { 2 - 4 }$(€)$ & $\leq 4$ to $\geq 1$ & $\leq 4$ to 0 & $\leq 2$ to 0 \\
\hline$\geq 0$ & 0.68 & 0.70 & 0.52 \\
$\geq 200$ & 0.54 & 0.55 & 0.38 \\
$\geq 400$ & 0.40 & 0.41 & 0.24
\end{tabular}

${ }^{1}$ Discrete time logistic survival model for cow disposal in any 50-d interval from first calving. 


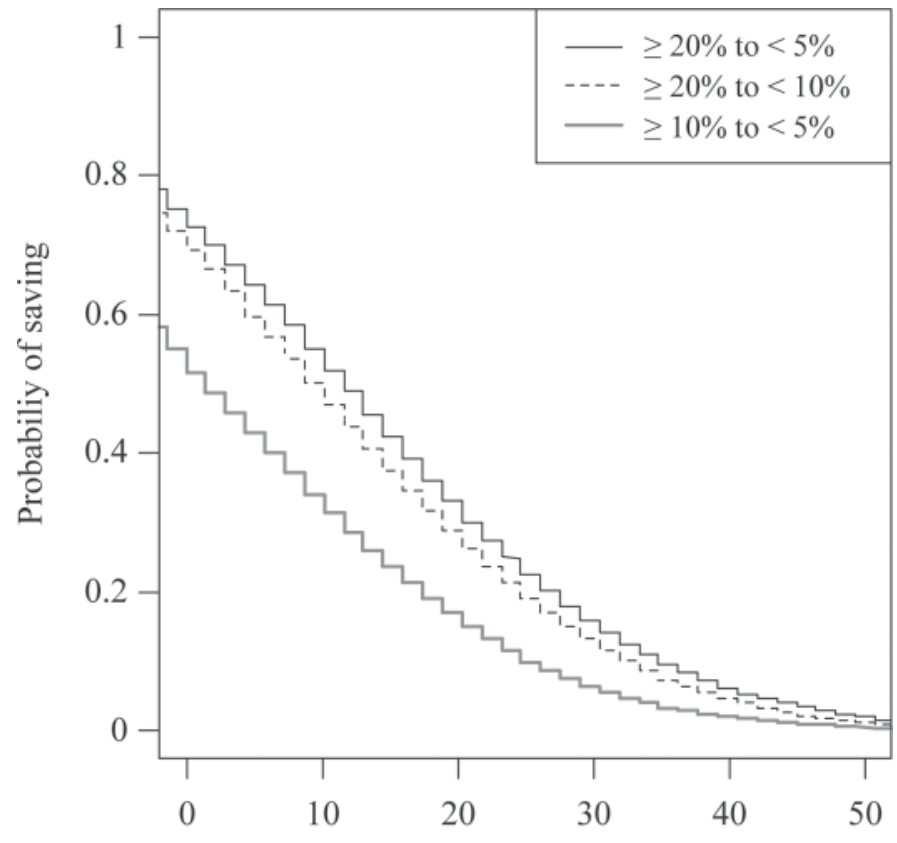

Minimum saving/heifer calved into the herd $(€)$

Figure 6. Micro-simulation over 10,000 simulations of Model 1 (discrete time logistic survival model for cow disposal in any 50-d interval from first calving); minimum saving per heifer calved into the herd attributable to reduction in replacement costs (probability of disposal within $1,750 \mathrm{~d}$ from first calving, multiplied by $€ 1,451 /$ cow replaced), for changes in the herd level prevalence of cows with SCC $\geq 400,000$ cells $/ \mathrm{mL}$ at 5 to 30 DIM during parity 1 .

between 5 and 30 DIM during parity 1 on other costs, such as lifetime milk yield, before the cost-effectiveness of specific interventions can be properly evaluated. Additional benefit may also exist through reduced incidence of clinical mastitis in particular herds.

This study highlights the usefulness and importance of generating predictions from statistical models to show the effect of results, because significant findings may not be biologically or economically meaningful when considered in context. Use of MCMC for predictions allows variability in parameters to be included, and therefore the full uncertainty in possible outcomes, as well as the central tendency, can be explored. For example, a conventional approach may base conclusions on the mean effect of SCC in early lactation on culling risk (De Vliegher et al., 2005), but variation in model parameters can affect the inference from these results (Green et al., 2010). The mean association of SCC early in the first lactation, and disposal in this research (Table 3), was less than that previously observed based on recorded culling dates over the first lactation (De Vliegher et al., 2005). However, cows in our study were followed up for over $5 \mathrm{y}$ and up to a maximum of 6 lactations, therefore the effect of SCC1 on disposal risk over a longer time period was less. This was also shown by introducing time-varying covariates for SCC (Table 3 ) and the associated reduction in the coefficient for SCC between 5 and 30 DIM during parity 1, which was consistent with previous work (De Vliegher et al., 2005).

With a more specific outcome definition (culling for udder health reasons only), strength of association with SCC early in the first lactation increased 3 fold (De Vliegher et al., 2005), emphasizing the importance of how an outcome is defined; although definitions and reliability of recording may also vary between herds. In the current study it was assumed that cows were disposed when recordings ceased (unless censored), although in reality it would likely be after this because of the logistics of economic carcass salvage. Despite this, trends in cow disposal appeared consistent with previous studies, indicating this was a reasonable proxy for culling. Specifically, cows in late lactation were at higher risk of disposal (Rajala-Schultz and Gröhn, 1999a,b), which varied seasonally (Anderson, 1985; Crosse and O' Donovan, 1989), and this could relate to an overall increased risk of disposal in the autumn for those cows in spring-calving herds that failed to conceive (Pinedo et al., 2010). Despite this, increasing milk yield decreased disposal risk (Beaudeau et al., 1994; Rajala-Schultz and Gröhn, 1999a).

Assessment of model fit for logistic regression models is not straightforward and is often neglected (Green et al., 2009). Demonstrating the extent to which models are useful, rather than simply correct, has been proposed as a rational approach to model assessment (Gelman et al., 1996). In this research, assessments of Model 1 based on aggregated predictions in groups of magnitude of SCC between 5 and 30 DIM during parity 1 suggested that predictions were reliable, and were likely generalizable to other Irish herds. This permitted use of a micro-simulation procedure to present the study results in a meaningful context.

\section{CONCLUSIONS}

Despite a negative association between SCC in the first month of lactation during parity 1 and longevity, the effect was small and, therefore, unlikely to be economically important when considered in isolation. Further research is required to evaluate the effect of SCC early in the first lactation on other costs, such as lifetime milk yield, and how this relates to cow longevity.

\section{ACKNOWLEDGMENTS}

Simon Archer was funded by a Teagasc Walsh Fellowship. The authors also thank the Irish Cattle Breeding Federation for access to their database. 


\section{REFERENCES}

Anderson, D. C. 1985. Wastage and disease in Bay of Plenty dairy herds. N. Z. Vet. J. 33:61-65.

Beaudeau, F., K. Frankena, C. Fourichon, H. Seegers, B. Faye, and J. P. T. M. Noordhuizen. 1994. Associations between health disorders of French dairy cows and early and late culling within the lactation. Prev. Vet. Med. 19:213-231.

Beaudeau, F., A. Henken, C. Fourichon, K. Frankena, and H. Seegers. 1993. Associations between health disorders and culling of dairy cows: A review. Livest. Prod. Sci. 35:213-236.

Berry, D. P., and A. R. Cromie. 2009. Associations between age at first calving and subsequent performance in Irish spring calving Holstein-Friesian dairy cows. Livest. Sci. 123:44-54.

Bradley, A. J., and M. J. Green. 2005. Use and interpretation of somatic cell count data in dairy cows. In Pract. 27:310-315.

Browne, W. J., and D. Draper. 2006. A comparison of Bayesian and likelihood based methods for fitting multilievel models. Bayesian Anal. 1:473-514.

Compton, C. W. R., C. Heuer, K. Parker, and S. McDougall. 2007. Epidemiology of mastitis in pasture-grazed peripartum dairy heifers and its effects on productivity. J. Dairy Sci. 90:4157-4170.

Crosse, S., and S. O' Donovan. 1989. Dairy cow disposal rates from commercial dairy farms participating in the DAIRYMIS II computerised management information system in Ireland. Ir. Vet. J. 42:75-78.

De Vliegher, S., H. W. Barkema, G. Opsomer, A. de Kruif, and L. Duchateau. 2005. Association between somatic cell count in early lactation and culling of dairy heifers using cox frailty models. J. Dairy Sci. 88:560-568.

Dohoo, I., W. Martin, and H. Stryhm. 2009. Veterinary Epidemiologic Research, 2nd ed. VER Inc., Charlottetown, Prince Edward Island, Canada.

Gelman, A., J. Carlin, H. Stern, and D. B. Rubin. 1995. Bayesian Data Analysis. Chapman \& Hall, London, UK.

Gelman, A., X. Meng, and H. Stern. 1996. Posterior predictive assessment of model fitness via realized discrepancies. Statist. Sinica 6:733-807.

Green, M. J., A. J. Bradley, G. F. Medley, and W. J. Browne. 2007. Cow, farm, and management factors during the dry period that determine the rate of clinical mastitis after calving. J. Dairy Sci. 90:3764-3776

Green, M. J., A. J. Bradley, G. F. Medley, and W. J. Browne. 2008. Cow, farm, and herd management factors in the dry period associated with raised somatic cell counts in early lactation. J. Dairy Sci. 91:1403-1415

Green, M. J., P. R. Burton, L. E. Green, Y. H. Schukken, A. J. Bradley, E. J. Peeler, and G. F. Medley. 2004. The use of Markov chain Monte Carlo for analysis of correlated binary data: Patterns of somatic cells in milk and the risk of clinical mastitis in dairy cows. Prev. Vet. Med. 64:157-174.

Green, M. J., G. F. Medley, A. J. Bradley, and W. J. Browne. 2010 Management interventions in dairy herds: Exploring within herd uncertainty using an integrated Bayesian model. Vet. Res. 41:22.

Green, M. J., G. F. Medley, and W. J. Browne. 2009. Use of posterior predictive assessments to evaluate model fit in multilevel logistic regression. Vet. Res. 40:30

Gröhn, Y. T., V. Ducrocq, and J. A. Hertl. 1997. Modeling the effect of a disease on culling: An illustration of the use of time-dependent covariates for survival analysis. J. Dairy Sci. 80:1755-1766.
Halasa, T., K. Huijps, O. Osteras, and H. Hogeveen. 2007. Economic effects of bovine mastitis and mastitis management: A review. Vet. Q. 29:18-31.

Heikkilä, A. M., J. I. Nousiainen, and S. Pyörälä. 2012. Costs of clinical mastitis with special reference to premature culling. J. Dairy Sci. 95:139-150.

Hennessy, T., B. Moran, A. Kinsella, and G. Quinlan. 2011. National Farm Survey 2010. Accessed May 18, 2012. www.teagasc.ie/ publications/2011/1016/NFS10.pdf.

Huijps, K., T. J. Lam, and H. Hogeveen. 2008. Costs of mastitis: Facts and perception. J. Dairy Res. 75:113-120.

ICBF. 2011. ICBF Dairy Cattle Statistics. Irish Cattle Breeding Federation, County Cork, Ireland. Accessed Nov. 3, 2012. http:// www.icbf.com/publications/files/national_stats/National_ Statistics_2011.pdf.

Kennedy, E., L. Shalloo, and F. Buckley. 2011. Optimising replacement heifer performance. Accessed May 18, 2012. http:// www.agresearch.teagasc.ie/moorepark/Articles/Optimising ReplacementHeiferPerformance_201101.pdf.

Kossaibati, M. A., and R. J. Esslemont. 1997. The costs of production diseases in dairy herds in England. Vet. J. 154:41-51.

Lehenbauer, T. W., and J. W. Oltjen. 1998. Dairy cow culling strategies: Making economical culling decisions. J. Dairy Sci. 81:264271.

Lunn, D. J., N. Best, and D. Spiegelhalter. 2000. WinBUGS-A Bayesian modelling framework: Concepts, structure, and extensibility. Stat. Comput. 10:325-337.

Madouasse, A. 2009. An evaluation of milk recording, somatic cell counts and reproductive performance in a large cohort of dairy herds in England and Wales. PhD Thesis. University of Nottingham, Nottingham, UK.

Pinedo, P. J., A. De Vries, and D. W. Webb. 2010. Dynamics of culling risk with disposal codes reported by dairy herd improvement dairy herds. J. Dairy Sci. 93:2250-2261.

R-Development-Core-Team. 2010. R: A language and environment for statistical computing. R Foundation for Statistical Computing, Vienna, Austria. Accessed Jun. 14, 2011. http://www.R-project.org.

Rajala-Schultz, P. J., and Y. T. Gröhn. 1999a. Culling of dairy cows. Part III. Effects of diseases, pregnancy status and milk yield on culling in Finnish Ayrshire cows. Prev. Vet. Med. 41:295-309.

Rajala-Schultz, P. J., and Y. T. Gröhn. 1999b. Culling of dairy cows. Part II. Effects of diseases and reproductive performance on culling in Finnish Ayrshire cows. Prev. Vet. Med. 41:279-294.

Rasbash, J., F. Steele, W. J. Browne, and H. Goldstein. 2009. A user's guide to MLwiN, v2.10. Centre for Multilevel Modelling, University of Bristol, Bristol, UK.

Seegers, H., F. Beaudeau, C. Fourichon, and N. Bareille. 1998. Reasons for culling in French Holstein cows. Prev. Vet. Med. 36:257-271.

Spiegelhalter, D. J., K. R. Abrams, and J. P. Myles. 2004. Bayesian Approaches to Clinical Trials and Health-Care Evaluation. Wiley, Chichester, UK.

Weigel, K. A., R. W. Palmer, and D. Z. Caraviello. 2003. Investigation of factors affecting voluntary and involuntary culling in expanding dairy herds in Wisconsin using survival analysis. J. Dairy Sci. $86: 1482-1486$ 